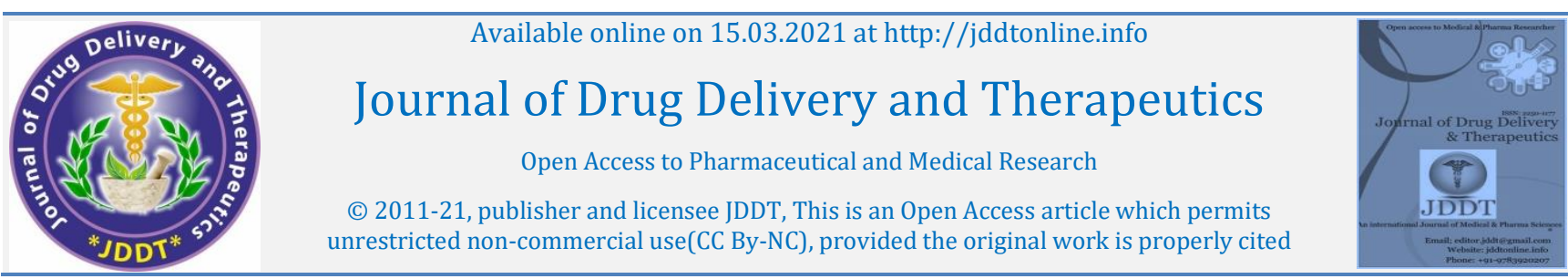

(C) 2011-21, publisher and licensee JDDT, This is an Open Access article which permits
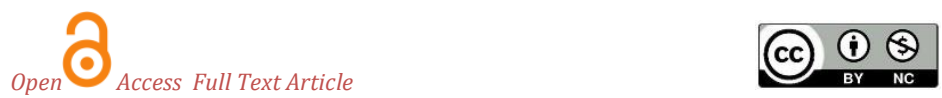

Research Article

\title{
Analysis of Achyranthes aspera L. extracts for their $\alpha$-Amylase and urease inhibitory activities
}

\author{
Ved Prakash*1 \& Anand Sagar ${ }^{2}$ \\ ${ }^{1}$ Department of Botany, Bhagat Singh Govt, P.G. College, Jaora (Ratlam) M.P. 457226 (India) \\ ${ }^{2}$ Department of Biosciences, Himachal Pradesh University, Summer Hill, Shimla, (H.P.) 171005 (India)
}

\section{Article Info:}

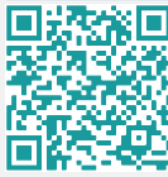

\section{Article History:}

Received 02 Dec 2020

Review Completed 08 Jan 2021

Accepted 17 Jan 2021;

Available online 15 March 2021

\section{Cite this article as:}

Prakash V, Sagar A, Analysis of Achyranthes aspera L. extracts for their $\alpha$-Amylase and urease inhibitory activities, Journal of Drug Delivery and Therapeutics. 2021; 11(2):108-112

DOI: http://dx.doi.org/10.22270/jddt.v11i2.4678

*Address for Correspondence:

Ved Prakash, Department of Botany, Bhagat Singh

Govt, P.G. College, Jaora (Ratlam) M.P. 457226 (India)

\section{Abstract}

Plant products have served as a major source of useful drugs for centuries and about half of the pharmaceuticals in use today are derived from these natural products. The efficacy and safety of herbal medicines have attracted the attention of scientists towards medicinal plants research. The present study was designed to investigate the whole plant extracts of Achyranthes aspera $\mathrm{L}$. for their anti-enzyme ( $\alpha$-amylae and urease) activity. All the extracts of $A$. aspera were reported to show good alpha-amylase and urease inhibitory activity of greater than $50 \%$ in all the solvents used at a concentration of $1 \mathrm{mg} / \mathrm{mL}$. $\alpha$ - amylase inhibition ranged from $17.66 \pm 0.10-69.90 \pm 0.50 \%$ whereas urease inhibitory activity ranged from $18.60 \pm 0.50$ to $79.90 \pm 0.50 \%$ suggesting a strong $\alpha$ - amylase and urease inhibitory effects of this plant. Thus the study provided scientific evidence to the traditional uses of this plant in the treatment of obesity, diabetes, ulcers, kidney stones intestinal infections etc. Therefore, the whole plant extracts of $A$. aspera can be selected for further investigation to find their therapeutic potential.

Keywords: Achyranthes aspera, plant extracts, $\alpha$-Amylase, Urease

\section{INTRODUCTION}

$\alpha$-Amylase and urease enzymes are often associated with a number of clinical conditions. Inhibitors of $\alpha$-Amylase serve as drug design targets for the treatment of certain disorders like diabetes, obesity and hyperlipaemia ${ }^{1}$. To overcome these detrimental effects and identify natural inhibitors of $\alpha$ amylases from plants is now the need of the hour. Likewise, urease contributes to arthritis, peptic ulcers and gastric intestinal infections ${ }^{2}$. Urease inhibitors may be effective therapies for the treatment of such disorders however, the commercially available urease inhibitors are of low stability and toxic which prevent their clinical use ${ }^{3}$. Hence, the search for novel urease inhibitors with improved stability and low toxicity is necessary in order to improve life quality of human beings and other animals ${ }^{4}$.

The secondary metabolites or chemical constituents present in the medicinal plants exhibit a wide range of therapeutic properties $^{5}$. The medicinal plant's role in retarding the vital metabolic pathways or inhibiting various enzymes is responsible for the biochemical reactions. Plant based products are being preferred as a promising source of lead molecules for new drug design and development ${ }^{6}$.

Achyranthes aspera L. (Family: Achyranthaceae) is an erect or procumbent, annual or perennial herb of about 1-2 $\mathrm{m}$ in height, often with a woody base. Traditionally, the plant is being used in indigenous system of medicine as emenagogue, antiarthritic, antifertility, antiphlegmatic, antiperiodic, purgative, laxative, ecbolic, abentifacient, antihelminthic, aphrodisiac, antiviral, antiplasmodic, antihypertensive, anticoagulant, diuretic and antitumor agent ${ }^{7,8}$. It is also useful to treat cough, asthma, oedema, renal dropsy, fistula, scrofula, skin rash, nasal, infection, chronic malaria, impotence, fever, piles and snake bites as well9-11. In view of its above mentioned useful properties, we planned to analyse $A$. aspera for its enzyme inhibitory activities (anti-alpha amylase and anti-urease).

\section{METHODOLOGY}

\section{Collection of plant material (study area)}

Fresh Leaves of Achyranthes aspera were plucked and collected from Devthana area of District Sirmaur, Himachal Pradesh, India. The collected plant material was brought to the laboratory for further investigations.

\section{Processing of plant material}

A. aspera whole plant parts were washed thoroughly under tap water and then with 2\% Mercuric chloride. Thereafter the parts were cut into smaller pieces for quick drying. The plant material thus obtained after drying was crushed into fine powder with the help of pestle mortar. At the end, fine 
powder was stored in air tight containers at room temperature.

\section{Enzyme inhibitory activity assays}

\section{$\alpha$ - Amylase inhibition assay}

$\alpha$ - Amylase inhibition of different plant extracts was determined by some modifications in the method reported by Giancarlo et al. ${ }^{12}$. The starch solution $(1 \% \mathrm{w} / \mathrm{v})$ was prepared by boiling and stirring $1 \mathrm{~g}$ of potato starch in 100 $\mathrm{mL}$ of sodium phosphate buffer for about 30 minutes. The porcine pancreatic $\alpha$ - amylase enzyme (EC 3.2.1.1; purchased from Sigma Aldrich-3176) was obtained by mixing $0.01 \mathrm{~g}$ of $\alpha$ - amylase in $10 \mathrm{~mL}$ of sodium phosphate buffer ( $\mathrm{pH}$ 6.9) having $0.0006 \mathrm{mM}$ sodium chloride $(\mathrm{NaCl})$. The whole plant extracts were dissolved in DMSO to give concentrations ranging from 0.2 to $1.0 \mathrm{mg} / \mathrm{mL}(0.2,0.4,0.6$, 0.8 and $1.0 \mathrm{mg} / \mathrm{mL}$ ). The colour reagent was used for the study (a solution containing $0.1 \mathrm{~g}$ of 3,5-dinitrosalicylic acid plus $2.99 \mathrm{~g}$ sodium potassium tartrate in $0.16 \mathrm{~g}$ sodium hydroxide and $10 \mathrm{~mL}$ phosphate buffer). $50 \mu \mathrm{L}$ of each plant extract plus $150 \mu \mathrm{L}$ of starch solution along with $10 \mu \mathrm{L}$ of enzyme were mixed in a 96 well-plate and incubated at $37^{\circ} \mathrm{C}$ for 30 minutes. Then $20 \mu \mathrm{L}$ of sodium hydroxide $(\mathrm{NaOH})$ and $20 \mu \mathrm{L}$ of colour reagent were added and the closed plate was placed into a water bath at $100^{\circ} \mathrm{C}$. After $20 \mathrm{~min}$, the reaction mixture was removed from the water bath, allowed for cooling and $\alpha$ - amylase activity was determined by measuring the absorbance of the mixture at $540 \mathrm{~nm}$ using a UV-VIS spectrophotometer. Blank samples, where the enzyme was replaced with the buffer solution were used to correct the absorption of the mixture. Apart from that, a control reaction was used, where the plant extract was replaced with $50 \mu \mathrm{L}$ of DMSO and the maximum enzyme activity was determined. Acarbose solution (a positive control) was used at a concentration range of 0.2-1.0 $\mathrm{mg} / \mathrm{mL}$. The complete experiment was performed in triplicate and the mean absorbance was taken to calculate percentage of $\alpha$ - amylase inhibition. The inhibition percentage was assessed by applying formula:

$$
\% \alpha \text {-Amylase inhibition }=\left(\frac{\Delta \text { Acontrol- } \Delta \text { Asample }}{\Delta \text { Acontrol }}\right) \times 100
$$

Where, $\Delta \mathrm{A}_{\text {control }}=\mathrm{A}_{\text {test }}-\mathrm{A}_{\text {Blank }}$

$$
\Delta \mathrm{A}_{\text {sample }}=\mathrm{A}_{\text {test }}-\mathrm{A}_{\text {Blank }}
$$

The concentration of the plant extract or inhibitor was determined from corresponding dose-response curves of inhibition percentage versus inhibitor concentration and compared to acarbose, a known inhibitor of $\alpha$ - amylase activity and a logarithmic regression curve was established to calculate the $\mathrm{IC}_{50}$ value (the concentration of the given sample required to inhibit the activity of urease enzyme by $50 \%$ ) for each sample. Data obtained were expressed as mean \pm standard deviation (S.D.).

\section{Urease inhibition assay}

The urease enzyme inhibition was determined through catalytic effects of urease on urea by measuring the change in absorbance in the absence and in the presence of inhibitor at $640 \mathrm{~nm}$, using UV-VIS spectrophotometer. The whole plant extracts that exerted significant inhibition were tested in a particular concentration range: $0.2,0.4,0.6,0.8$ and 1.0 $\mathrm{mg} / \mathrm{mL}$. Just after addition of $10 \mathrm{~mL}$ of phosphate buffer to accurate weight of enzyme, sonication was performed for about 60 seconds which was followed by centrifugation and absorbance of upper solution was measured at $280 \mathrm{~nm}$. One can measure the concentration of initial urease solution by using equation $A=\varepsilon b c$, where $c$ is concentration of solution (mol/L), b is length of the UV cell and $\varepsilon$ represents molar absorptivity. The concentration of enzyme solution was then adjusted to $2 \mathrm{mg} / \mathrm{mL}$ following proper dilution. The reaction mixture containing $1.2 \mathrm{~mL}$ of phosphate buffer solution $(10$ $\mathrm{mM}$ potassium phosphate, $10 \mathrm{mM}$ lithium chloride and $1 \mathrm{mM}$ EDTA, pH 8.2 at $37^{\circ} \mathrm{C}$ ), $0.2 \mathrm{~mL}$ of urease enzyme solution and $0.1 \mathrm{~mL}$ of test compound was subjected to incubation for about $5 \mathrm{~min}$. After pre-incubation, $0.5 \mathrm{~mL}(66 \mathrm{mM})$ of urea was added to the reaction mixture and then incubated for 20 min. Finally, urease activity was determined by measuring the ammonia released during the reaction by modified spectrophotometric method as described by Weatherburn ${ }^{13}$. Briefly, $1 \mathrm{~mL}$ of phenol reagent $(1 \% \mathrm{w} / \mathrm{v}$ sodium nitroprusside) and $1 \mathrm{~mL}$ of an alkaline reagent $(1 \% \mathrm{w} / \mathrm{v}$ $\mathrm{NaOH}$ and $0.075 \%$ active chloride $\mathrm{NaOCl}$ ) were added to each test tube used. The control contained all the required reagents except the test sample. Thiourea i.e. standard inhibitor was used as a positive control. The increase in absorbance at $640 \mathrm{~nm}$ was measured after $30 \mathrm{~min}$ using a UV-VIS spectrophotometer. The inhibition percentage was determined using following formula:

$$
\% \text { Urease Inhibition }=\left(\frac{\mathrm{Ac}-\mathrm{As}}{\mathrm{Ac}}\right) \times 100
$$

Where, $A_{s}=$ absorbance of the sample under study

$$
\mathrm{A}_{\mathrm{c}}=\text { absorbance of the control }
$$

Each experiment was performed thrice to calculate the average. Data thereby were expressed as mean \pm standard deviation (S.D.). $\mathrm{IC}_{50}$ values for each sample were determined from the dose-response curves.

\section{RESULTS}

In the present investigation, the leaf extracts (methanol, acetone and aqueous) of $A$. aspera were tested for their enzyme inhibitory activity against $\alpha$-amylase and urease enzymes and it was observed that all the extracts showed strong inhibition at a concentration of $1 \mathrm{mg} / \mathrm{mL}$. The inhibitory activity increased with increasing the concentration of each plant extract in specified range of 0.2 $1.0 \mathrm{mg} / \mathrm{mL}$. At a concentration of $1 \mathrm{mg} / \mathrm{mL}$, the inhibitory activity of $\alpha$-amylase was $69.90 \pm 0.50$ (IC50: $0.58 \mathrm{mg} / \mathrm{mL}$ ), $59.00 \pm 1.30$ (IC $50: 0.82 \mathrm{mg} / \mathrm{mL}$ ) and $46.65 \pm 0.42 \%$ (IC $50: 1.06$ $\mathrm{mg} / \mathrm{mL}$ ) for methanol, acetone and aqueous extract respectively as shown in Table 1 . The results were compared with standard acarbose which showed greater inhibition $(78.56 \pm 0.45 \%)$ with lowest $\mathrm{IC}_{50}$ value of $0.53 \mathrm{mg} / \mathrm{mL}$ which is greater than plant extract. The results further indicated that methanol extracts showed maximum inhibitory effects than other solvent extracts.

Furthermore, the urease inhibitory activity of $A$. aspera leaf extracts was studied against jack bean urease by using phenol hypochlorite method as compiled in Table 2 . All the three extracts (methanol, acetone and aqueous) were reported to exert significant inhibitory effects on jack bean urease enzyme. Among these, methanol extract showed maximum inhibition of $79.90 \pm 0.50 \%$ followed by acetone $(62.60 \pm 1.30)$ and aqueous extract $(49.54 \pm 0.42)$ with IC $_{50}$ value of $0.56,0.79$ and $1.01 \mathrm{mg} / \mathrm{mL}$ respectively. Further, Thiourea (standard) showed better urease inhibition $(81.26 \pm 1.25)$ as compared to plant extracts.

\section{DISCUSSION}

Inhibition of $\alpha$-amylase delays the digestion process by hampering breakdown of starch and therefor can be used as an effective strategy for regulating hyper-glycemic condition ${ }^{14}$. This endocrine disorder is often characterized by hyper-glycemic spike because of impaired insulin secretion and insulin sensitivity ${ }^{15}$. The postprandial phase of 
diabetes is distinctive and peculiar due to the elevated glycated hemoglobin (HbA1c) level leading to several macro as well as micro-vascular complications such as retinopathy, neuropathy and increased risk of cardiovascular diseases ${ }^{16}$.

Furthermore, the medicinal plants have been widely used for their therapeutic potential in controlling various disorders caused by urease enzyme. Scientists are unifying traditional knowledge with experimental methodology for determining the efficacy and safety of herbal preparations ${ }^{17}$. Rural population of India, like most developing countries, heavily relies on valuable heritage of medicinal plants and their products. It is therefore of great interest to find out the possible reasons for efficacy of indigenous medicinal plants which are commonly used by local population and traditional practitioners. Jack bean urease enzyme has been used in the current study because it shares more than $50 \%$ similarity with the bacterial urease and also it has been found that the mechanism of action and the kinetics of inhibition for bacterial urease and jack bean urease are similar to greater extent ${ }^{18}$.

Current study presents an investigation of different extracts of $A$. aspera for their enzyme inhibitory activity (against $\alpha$ amylase and urease). From the results it was found that the plant was more effective against urease than $\alpha$ - amylase as all the three leaf extracts displayed better inhibition of $\alpha$ amylase as compared to urease. In case of $\alpha$ - amylase, methanol leaf extract showed maximum inhibition of $69.90 \pm 0.50 \%$ whereas for methanol extract of $A$. aspersa against urease, maximum inhibition of $79.90 \pm 0.50 \%$ was reported which is more than $\alpha$ - amylase. The plant extracts showed concentration dependent inhibition of enzymes as shown in Fig. 1 and 2. Against both the enzymes, aqueous extract proved to be least effective which indicated that the water soluble constituents of $A$. aspera have little ability to inhibit these enzymes. The results further confirmed that methanol extracts exhibited maximum inhibitory effects than other solvent extracts against both the enzymes. This tends to show that the active constituents or metabolites of the different plant parts are better extracted with methanol as solvent.

Rani et al.19 evaluated the effects of alcoholic extract of Acyhranthes aspera leaves on carbohydrate absorption and thus reported that the plant inhibited $\alpha$-amylase enzyme in dose-dependent manner. The results of the present study are also in agreement with these findings since we reported $69.90 \%$ inhibition of $\alpha$-amylase by methanol leaf extract of this plant.

Ali et al. ${ }^{20}$ investigated alcoholic leaf extract of $A$. aspera for its antiurease activity. Results showed considerable enzyme inhibitory (97.64\%) activity at a concentration of $5 \mathrm{mg} / \mathrm{mL}$ while in the present study methanol extract of $A$. aspera displayed $79.90 \%\left(\mathrm{IC}_{50}=0.56 \mathrm{mg} / \mathrm{mL}\right)$ inhibition of urease enzyme at a concentration of $1 \mathrm{mg} / \mathrm{mL}$.

Although, present investigations are of preliminary type, yet they have established a base for further extension of this work towards isolation and purification of bioactive compounds present in Achyranthes aspera responsible for its medicinal activity.

Table 1: $\alpha$-Amylase inhibitory activity (\%) of $A$. aspera leaf extracts at different concentrations

\begin{tabular}{ccccc}
\hline $\begin{array}{c}\text { Concentration } \\
(\mathrm{mg} / \mathrm{mL})\end{array}$ & Methanol extract & Acetone extract & Aqueous extract & Acarbose \\
0.2 & $28.15 \pm 0.55$ & $22.85 \pm 0.30$ & $17.66 \pm 0.10$ & $29.50 \pm 0.70$ \\
0.4 & $41.77 \pm 0.24$ & $28.05 \pm 0.55$ & $25.90 \pm 1.15$ & $40.85 \pm 2.15$ \\
0.6 & $54.20 \pm 0.12$ & $37.00 \pm 2.05$ & $31.00 \pm 0.20$ & $56.45 \pm 1.25$ \\
0.8 & $60.72 \pm 2.20$ & $50.30 \pm 0.66$ & $42.25 \pm 0.18$ & $66.22 \pm 0.52$ \\
1.0 & $69.90 \pm 0.50$ & $59.00 \pm 1.30$ & $46.65 \pm 0.42$ & $78.56 \pm 0.45$ \\
$\mathrm{IC} 50(\mathrm{mg} / \mathrm{mL})$ & 0.58 & 0.82 & 1.06 & 0.53 \\
\hline
\end{tabular}

Values are given as mean \pm S.E.

Table 2: Urease inhibitory activity (\%) of A. aspera leaf extracts at different concentrations

\begin{tabular}{ccccc}
\hline $\begin{array}{c}\text { Concentration } \\
(\mathrm{mg} / \mathrm{mL})\end{array}$ & Methanol extract & Acetone extract & Aqueous extract & Thiourea \\
0.2 & $25.05 \pm 1.55$ & $20.80 \pm 0.35$ & $18.60 \pm 0.50$ & $28.38 \pm 0.78$ \\
0.4 & $38.77 \pm 0.50$ & $27.05 \pm 0.55$ & $26.90 \pm 1.15$ & $41.58 \pm 0.55$ \\
0.6 & $50.00 \pm 0.10$ & $37.00 \pm 3.00$ & $33.00 \pm 0.00$ & $56.30 \pm 1.20$ \\
0.8 & $68.76 \pm 2.25$ & $50.35 \pm 0.66$ & $42.25 \pm 0.10$ & $69.20 \pm 0.50$ \\
1.0 & $79.90 \pm 0.50$ & $62.60 \pm 1.30$ & $49.54 \pm 0.42$ & $81.26 \pm 1.25$ \\
$\mathrm{IC}$ & 0.56 & 0.79 & 1.01 & 0.51 \\
\hline
\end{tabular}

Values are given as mean \pm S.E. 


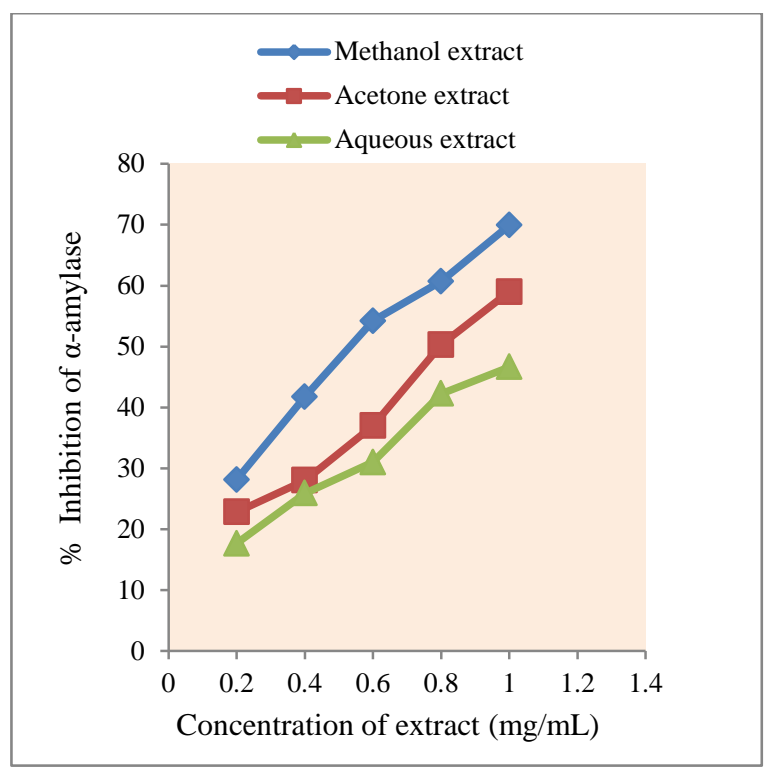

Figure 1: $\alpha$-amylase inhibition profile of different extracts of A. aspera against porcine $\alpha$-amylase. The extracts were tested at a concentration range i.e. $0.2-1.0 \mathrm{mg} / \mathrm{mL}$. The activity altogether increased with increase in concentration of extract. Vertical bars show mean \pm standard error.

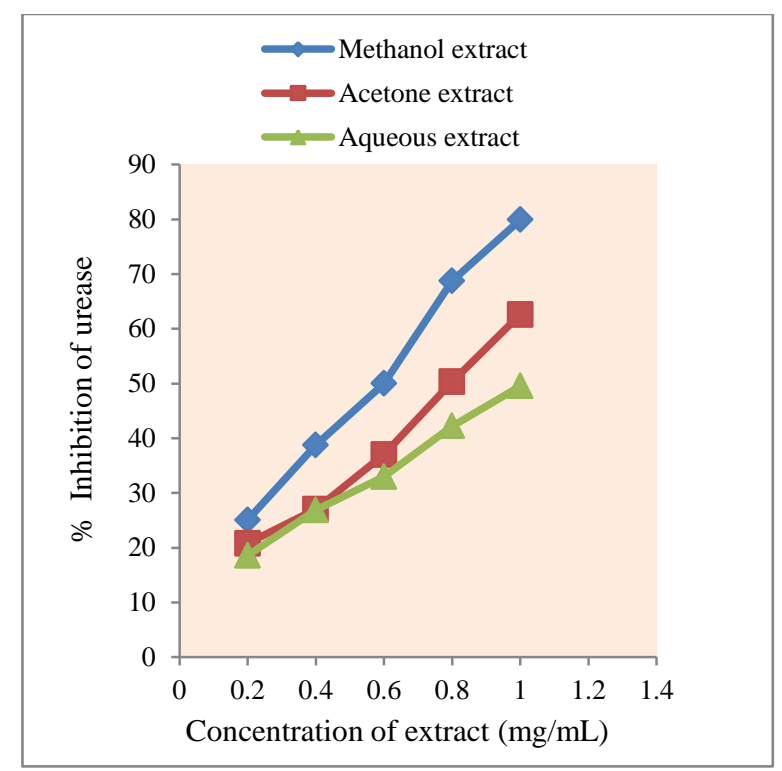

Figure 2: Urease inhibition profile of different extracts of $A$. aspera against porcine $\alpha$-amylase. The extracts were tested at a concentration range i.e. $0.2-1.0 \mathrm{mg} / \mathrm{mL}$. The activity altogether increased with increase in concentration of extract. Vertical bars show mean \pm standard error.

\section{CONCLUSION}

As a conclusion, it could be speculated that the results of $\alpha$ amylase and urease inhibitory studies are quite encouraging as all the tested leaf extracts (methanol, acetone and aqueous) of Achyanthes aspera exhibited significant inhibition. $\alpha$ - amylase inhibition ranged from $17.66 \pm 0.10$ $69.90 \pm 0.50 \%$. Similarly, urease inhibitory activity ranged from $18.60 \pm 0.50$ to $79.90 \pm 0.50 \%$ suggesting a strong $\alpha$ amylase and urease inhibitory effects of this plant. Apart from this, methanol extracts were found to be more effective against both the enzymes used compared to acetone and aqueous extracts. It is clear from the results that whole plant extracts under study displayed variable enzyme ( $\alpha$ - amylase and urease) inhibitory activities thereby confirming their roles in the treatment of various diseases caused by the malfunctioning of these enzymes. Further research is required to find the exact mechanism of action and the chemical constituents of this plant responsible for its enzyme inhibitory activity.

\section{ACKNOWLEDGEMENT}

Authors want to put on record their gratitude to the Chairman, Department of Biosciences, Himachal Pradesh University, Summer Hill, Shimla (India) for providing essential Lab facilities. First author greatly acknowledges the financial support provided by Indian Council of Medical Research (ICMR), New Delhi to conduct this work smoothly.

\section{CONFLICT OF INTEREST}

The authors hereby declare that there is no conflict of interest regarding the manuscript and experimentation done.

\section{REFERENCES}

1. Eichler HG, Korn A, Gasic S, Pirson W, Businger J, The effect of a new specific alpha-amylase inhibitor on post-prandial glucose and insulin excursions in normal subjects and type 2 (noninsulin-dependent) diabetic patients, Diabetologia, 1984; 26:278-281.

2. Macegoniuk $\mathrm{K}$, Inhibitors of bacterial and plants urease: $\mathrm{A}$ review, Folia Biologica et Oecologica, 2013; 9:9-16.

3. Azizian H, Nabati F, Sharifi A, Siavoshi F, Mahdayi M, Amanlou $\mathrm{M}$, Large scale virtual screening for the identification of new Helicobacter pylori urease inhibitor scaffolds, Journal of Molecular Modeling, 2012; 18:2917-2927.

4. Prakash V, Rana S, Sagar A, Studies on analysis of antioxidant and enzyme inhibitory activity of Vitex negundo Linn., International Journal of Pharmacognosy and Phytochemical Research, 2017; 9:833-839.

5. Prakash V, Sagar A, Jhamta R, Kaundal P, Rana S, Kumari K, Rana J, To screen some medicinal plants of District Sirmaur, Himachal Pradesh for the presence of different phytochemicals in them, Plant Archives. 2019; 2321-2324.

6. Pavithra MKS, Kannan KM, In vitro enzyme inhibitory and cytotoxic studies with Evolvulus alsinoides (Linn.) Linn. Leaf extract: a plant from Ayurveda recognized as Dasapushpam for the management of Alzheimer's disease and diabetes mellitus, BMC Complementary Medicine and Therapies, 2020; 20:1-12.

7. Anonymous, The Wealth of India, Raw Materials. New Delhi: Publication and Information Directorate, Center for Scientific and Industrial Research (CSIR), 1985; 57:168-170.

8. Selvanayagam ZE, Gnanavendan SG, Balakrishnan K, Rao RB, Anti-snake venom botanicals from ethnomedicine, Journal of Herbs, Spices and Medicinal Plants, 1994; 2:45-100.

9. Ratra PS, Misra K C, Seasonal variation in chemical composition of $A$. aspera and A. bidentata, Indian Forester, 1970; 96:372-375.

10. Singleton P, Bacteria in Biology, Biotechnology and Medicine. Fourth edition. New York, John Wiley and Sons Ltd. 1999.

11. Shukla R, Chakravarty M, Gautam MP, Indigenous medicine used for treatment of gynecological disorders by tribals of Chhattisgarh, India, Journal of Medicinal Plants Research, 2008; 2:356-360.

12. Giancarlo S, Rosa LM, Nadjafi F, Francesco M, Hypoglycaemic activity of two spices extracts: Rhus coriaria L. and Bunium persicum, Natural Products Research, 2006; 20:882-886.

13. Weatherburn MW, Phenol hypochlorite reaction for determination of ammonia, Analytical Chemistry, 1967; 39:971974.

14. Ashok KBS, Lakshman K, Nandeesh R, Kumar PA, Manoj B, Kumar V, In vitro alpha-amylase inhibition and in vivo antioxidant potential of Amaranthus spinosus in alloxan-induced oxidative stress in diabetic rats, Saudi Journal of Biological Sciences, 2011; 18:15.

15. Nyenwe EA, Jerkins TW, Umpierrez GE, Kitabchi AE, Management of type 2 diabetes: Evolving strategies for the treatment of patients with type 2 diabetes, Metabolism, 2011; 60:1-23. 
16. Bonora E, Muggeo M, Post-prandial blood glucose as a risk factor for cardiovascular disease in type 2 diabetes: The epidemiological evidence, Diabetologia, 2001; 44:2107-2114.

17. Ahmed D, Ejaz N, Saeed R, Dar P, Cooking effect on antioxidative and alpha-amylase inhibitory potential of aqueous extract of Lagenaria siceraria fruit and its nutritional properties, Free Radicals and Antioxidants, 2016; 6:44-50.

18. Ciurli S, Benini S, Rypniewski WR, Wison KS, Miletti S, Mangani $S$, Structural properties of the nickel ions in urease: Novel insight into the catalytic and inhibition mechanisms. Coordination Chemistry Reviews, 1999; 190:331-335.

19. Ran N, Sharma SK, Vasudeva N, Assessment of anti-obesity potential of Achyranthes aspera Linn. Seed, Evidence-Based Complementary and Alternative Medicine, 2012; 1-7.

20. Ali I, Mabunni S, Mounica N, Kuldeep P, Kumar TJ, In vitro urease inhibitory activity of four selected medicinal plant extracts, International Journal of Pharma Research and Health Sciences, 2015; 3:891-894. 